\title{
Comparison between Acetate versus Bicarbonate dialysate during Hemodialysis among Acute Renal Failure Patients, Assuit University hospital
}

\author{
Naglaa Ahmed Ahmed Elrashedy, Warda Youssef Mohammed, Maher Abd El Naser. Mona Ali Mohammed, \\ \& Mervat Anwar Abdel-Aziz.
}

Assistant lecturer of Critical Care Nursing, Faculty of Nursing, Assiut University

Professor of Critical Care \& Emergency Nursing, Faculty of Nursing, Cairo University

Professor of Internal Medicine, Faculty of Medicine, Assiut University

Lecturer in Critical Care Nursing, Faculty of Nursing, Assiut University

\begin{abstract}
:
Critically ill patients with acute renal failure who are receiving dialysis therapy may suffer from many complications that can be decreased by using bicarbonate dialysate during dialysis sessions. Aim: this study was carried out to compare between the hemodialized acute renal failure patientsusing bicarbonate versus acetate dialysate ondeveloping complications. Design: descriptive comparative designutilized in this study. Setting: This study was carried out at the kidney dialysisunit, Assiut University Hospital. Subjects Sixty adult male and female critically ill patients with acute renal failure who are admitted to the kidney dialysis unit (how many using bicarbonate and how many using acetate and how you selected them).Tool:"hemodialysis patient observational and monitoring tool" was used to monitor and record the personal and medical data needed for this study by the researcher.Methods: Interview, observation and reviewing patient's records were utilized to collect data pertinent to the study. Each patient was monitored closely ten minutes before connection to the dialysis machine, during the dialysis session and ten minutes after disconnection, three times per week for two successive weeks. Results: The patients on the acetate group had experienced many problems (tachycardia, hypotension and dyspnea). There was a significant statistical difference between both groups with ( $\mathrm{p}$ value $=0.001$ ). Conclusion: the group of patients on bicarbonate dialysate during dialysis sessions was found to experience lesser problems than acetate dialysis group.
\end{abstract}

Key words: Acetate solution, Bicarbonate solutions, Hemodialysis and Critically ill Patients.

\section{Introduction:}

Critically ill patients with acute renal failure(ARF) experienced longer length of hospital stay and more complications, and the mortality rate rises dramatically in such patients.It was documented that they often have associated multiple organ dysfunction syndrome (MODS) and more complex illnesses.Moreover, the criticallyill patients who are receiving dialysis therapies in the critical care unit typicallyare not admitted to the critical care unit with a diagnosis of ARF alone; there is always coexisting hemodynamic, cardiac, pulmonary, or neurologic compromise. (kellum, 2008)

Acute renal failuremay lead to number of complications, including metabolic acidosis, high potassium and blood urea levels, changes in the body fluid balance, and other effects to theorgan systems.Symptoms of acute kidney injury result from various disturbances of kidney function that are associated with the disease. Accumulation of urea and other nitrogen-containing substances in the blood stream lead to a number of symptoms, such as fatigue, loss of appetite, headache, nausea and vomiting, with marked increases in the potassium level that can lead to dysrhythmia (Wesberg, 2009).
The dialysate solutionis composed of water and major electrolytes of normal serum. It is made in a clean system with filtered taps water and chemicals In the hemodialysis unit there are two types of dialysate solutions: acetate and bicarbonate dialysate solutions. Choosing the type of dialysate solutions depend on the blood pressure value. (Jonathan et al 2012). Acetate containing dialysate solution can be used with routine hemodialysis patients who are hemodynamically stable with mild to moderate acidosis. Acetate solution is known as a vasodilator that leads to headache and hypotension when high efficiency dialysis is used.(Gonce et al 2010)

The role of the critical care nurse is very important during dialysis session for assessing, monitoring, and evaluating fluid balance and hemodynamic stability during the hemodialysis session. The critical care nurse monitorsblood pressure, pulse, weight, fluid intake and output, skin turgor, and central venous pressure valuethat help determine fluid overload.She should reviewthe patient's history and the clinical findings, and the response to dialysis treatment. Moreover, the critical care nurse should frequently send blood sample for laboratory examinations to check the coagulation abnormalities and electrolytes 
changes, acid base balance and arterial blood gases to assess oxygenation and ventilation status (Gonce et al 2010).

Aim of the Study:

Theaim of this study was to compare between the hemodialized acute renal failure patients using bicarbonate versus acetate dialysate solution on developing complications (hemodynamic complications, and blood coagulation profile changes).

To fulfill the aim of this study the following research questions were formulated:

\section{Research questions:}

A. What is the effect of acetate dialysate solution on hemodynamic status, and blood coagulation profile among hemodialized acute renal failure patients?

B. What is the effect of bicarbonate dialysate solution on hemodynamic status, and blood coagulation profile among hemodialized acute renal failure patients?

\section{Patients and Method}

Research design:

Descriptive comparative research design was utilized in this study.

\section{Setting of the study:}

\section{Results:}

Table (1): Characteristics of the studied patients in the acetate and bicarbonate groups

\begin{tabular}{|c|c|c|c|c|}
\hline \multirow{2}{*}{$\begin{array}{l}\text { Types of solutions } \\
\text { Variables }\end{array}$} & \multicolumn{2}{|c|}{ Acetate solutionG1 } & \multicolumn{2}{|c|}{ Bicarbonate solution G2 } \\
\hline & $\mathbf{N}$ & $\%$ & $\mathbf{N}$ & $\%$ \\
\hline $\begin{array}{l}\text { 1-Age groups } \\
-\quad 20<29 \text { years } \\
-\quad 30<39 \text { years } \\
-\quad 40<49 \text { years } \\
-50<60 \text { years }\end{array}$ & $\begin{array}{c}5 \\
13 \\
7 \\
5\end{array}$ & $\begin{array}{l}16.6 \\
43.3 \\
23.3 \\
16.6\end{array}$ & $\begin{array}{c}7 \\
12 \\
5 \\
6\end{array}$ & $\begin{array}{c}23.3 \\
40.0 \\
16.6 \\
20\end{array}$ \\
\hline - The mean \&St. D of age & \multicolumn{2}{|c|}{$41.9 \pm 10.0$} & \multicolumn{2}{|c|}{$38.6 \pm 13.7$} \\
\hline $\begin{array}{c}\text { 2- Gender } \\
\text { - Male } \\
\text { - Female }\end{array}$ & $\begin{array}{l}11 \\
19\end{array}$ & $\begin{array}{l}36.7 \\
63.3\end{array}$ & $\begin{array}{l}15 \\
15\end{array}$ & $\begin{array}{l}50 \\
50\end{array}$ \\
\hline $\begin{array}{l}\text { 3- Types of ICUs } \\
\text { - Medical (ICU) } \\
\text { - Medical reception (ICU) } \\
\text { - CCU } \\
\text { - Obstetric (ICU) } \\
\text {-Trauma (ICU) }\end{array}$ & $\begin{array}{l}18 \\
8 \\
4 \\
0 \\
0\end{array}$ & $\begin{array}{c}60.0 \\
26.7 \\
13.3 \\
0.0 \\
0.0\end{array}$ & $\begin{array}{c}11 \\
2 \\
0 \\
10 \\
7\end{array}$ & $\begin{array}{c}36.7 \\
6.7 \\
0.0 \\
33.3 \\
23.3\end{array}$ \\
\hline
\end{tabular}

Chi-square test

**highly statistical significant difference $(\mathrm{P}<0.05)$
This study was conducted in the kidney dialysis unit at Assiut University Hospital.

\section{Sample:}

Sixty adult male and female critically ill patients with acute renal failure, admitted to the kidney dialysis unit for the first time and ready to participate in this study. The patients were matched and divided randomly into two equal groups (acetate and bicarbonate, thirty each).

\section{Matching criteria:}

$\checkmark$ Age nearly as the same in each group

$\checkmark$ Sex nearly as the same in each group

\section{Study tools:}

One tools it is only one tool you mentioned that before and consisted of three parts developed by the researcher and used in this study. (The tools were revised by 3 nursing staff in critical care nursing and 3 medical experts, and tested then piloted by the investigator to be utilized in this study.

\footnotetext{
.
} 
Figure (1): Percentage distribution of the studied patients in the both groups in relation to the predisposing factors of acute renal failure.

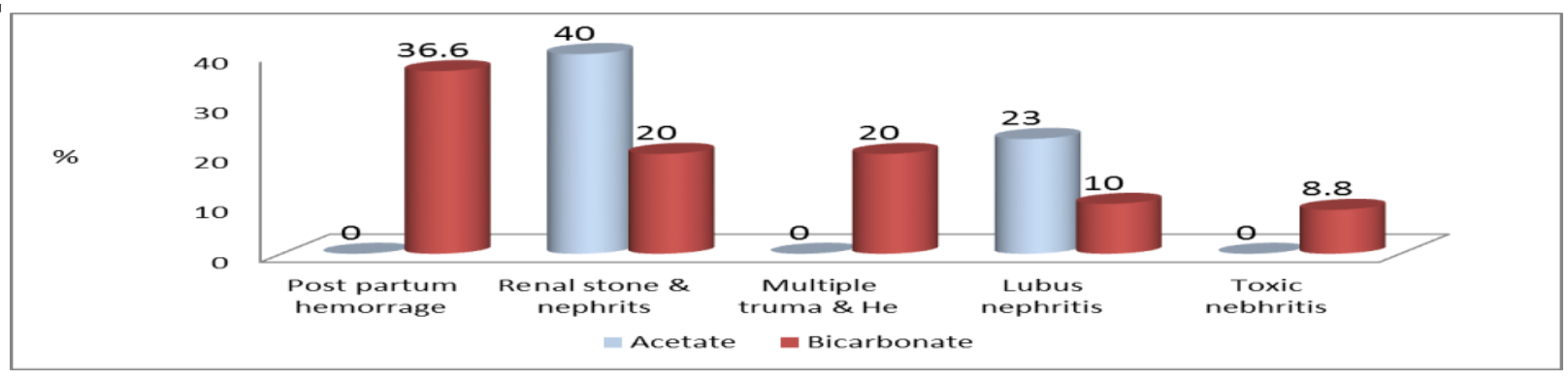

Table 2: Comparison between the both groups in relation to the vital signs values before and after the dialysis sessions.

\begin{tabular}{|c|c|c|c|c|c|c|}
\hline \multirow{2}{*}{$\begin{array}{c}\text { Vital signs } \\
1- \\
\text { Temperature }\end{array}$} & \multicolumn{3}{|c|}{ Acetate solution (mean + SD) G1 } & \multicolumn{3}{|c|}{ Bicarbonate solution (mean + SD) G2 } \\
\hline & $\begin{array}{c}\text { Before } 10 \\
\text { min }\end{array}$ & After $10 \mathrm{~min}$ & P. value & $\begin{array}{c}\text { Before } 10 \\
\text { min }\end{array}$ & $\begin{array}{c}\text { After10 } \\
\text { min }\end{array}$ & P. value \\
\hline $\begin{array}{l}-1^{\text {st }} \text { week } \\
-2^{\text {nd }} \text { week } \\
\end{array}$ & $\begin{array}{l}37.4+0.3 \\
37.4+0.2 \\
\end{array}$ & $\begin{array}{l}33.7+7.5 \\
36.4+3.8 \\
\end{array}$ & $\begin{array}{l}0.001 \\
0.155 \\
\end{array}$ & $\begin{array}{l}37.5+0.3 \\
38.5+7.4 \\
\end{array}$ & $\begin{array}{l}37.3+1.8 \\
37.3+0.2 \\
\end{array}$ & $\begin{array}{l}0.989 \\
0.378 \\
\end{array}$ \\
\hline P. value & 0.986 & 0.002 & & 0.462 & 0.998 & \\
\hline \multicolumn{7}{|l|}{ 2- Respiration } \\
\hline $\begin{array}{l}-1^{\text {st }} \text { week } \\
-2^{\text {nd }} \text { week }\end{array}$ & $\begin{array}{c}18.2+2.1 \\
18.5+2 \\
\end{array}$ & $\begin{array}{l}21.3+3.7 \\
22.2+3.7\end{array}$ & $\begin{array}{l}0.001 \\
0.001\end{array}$ & $\begin{array}{c}16.9+2.4 \\
17+2.5\end{array}$ & $\begin{array}{l}20.9+3.4 \\
20.5+4.3 \\
\end{array}$ & $\begin{array}{l}0.001 \\
0.001\end{array}$ \\
\hline P. value & 0.241 & 0.120 & & 0.811 & 0.499 & \\
\hline \multicolumn{7}{|l|}{ 3- Heart rate } \\
\hline $\begin{array}{l}-1^{\text {st }} \text { week } \\
-2^{\text {nd }} \text { week }\end{array}$ & $\begin{array}{l}81.2+12 \\
73.5+9.7\end{array}$ & $\begin{array}{l}81.9+16 \\
73+11.5\end{array}$ & $\begin{array}{l}0.626 \\
0.715\end{array}$ & $\begin{array}{l}104.8+10.6 \\
100.9+14.4\end{array}$ & $\begin{array}{c}89.5+16.1 \\
85+14.2\end{array}$ & $\begin{array}{l}0.354 \\
0.896\end{array}$ \\
\hline P. value & 0.001 & 0.001 & & 0.002 & 0.050 & \\
\hline \multicolumn{7}{|c|}{ 4-Blood pressure } \\
\hline$-1^{\text {st }}$ week & $\begin{array}{c}163.1+7.7 / \\
96.6+4.7\end{array}$ & $\begin{array}{c}120.6+20.7 / \\
84.5+11.9\end{array}$ & 0.001 & $\begin{array}{l}92.3+21.2 / \\
58.5+10.7\end{array}$ & $\begin{array}{c}105+28 / \\
80.1+16.6 \\
\end{array}$ & $\begin{array}{l}0.051 \\
0.359 \\
\end{array}$ \\
\hline$-2^{\text {nd }}$ week & $\begin{array}{c}162+7.9 / \\
98.9+3\end{array}$ & $\begin{array}{c}115.3+19.3 / \\
86.5+10.2\end{array}$ & $\begin{array}{l}0.001 \\
0.001\end{array}$ & $\begin{array}{c}89.1+24.8 / \\
66.4+13.8\end{array}$ & $\begin{array}{c}99.8+24.1 / \\
69.3+14.3\end{array}$ & 0.001 \\
\hline P. value & 0.001 & 0.227 & & 0.036 & 0.457 & \\
\hline
\end{tabular}

Table 3: Comparison between the both groups in relation to the vital signsvaluesduring the dialysissessions.

\begin{tabular}{|c|c|c|c|}
\hline \multirow{2}{*}{ Vital signs } & \multicolumn{2}{|c|}{ During dialysis session } & \multirow{2}{*}{ T. test } \\
\hline & Acetate G1 & Bicarbonate G2 & \\
\hline \multicolumn{4}{|l|}{ 1-Temperature } \\
\hline$-1^{\text {st }}$ week & $37.3+0.2$ & $37.5+0.2$ & 0.002 \\
\hline$-2^{\text {nd }}$ week & $37.2+0.2$ & $37.4+0.2$ & 0.002 \\
\hline P. value & 0.057 & 0.057 & \\
\hline \multicolumn{4}{|l|}{ 2- Respiration } \\
\hline$-1^{\text {st }}$ week & $25+2.9$ & $19.4+2.6$ & 0.001 \\
\hline$-2^{\text {nd }}$ week & $23.3+2.1$ & $22.2+2.5$ & 0.070 \\
\hline P. value & 0.380 & 0.675 & \\
\hline \multicolumn{4}{|l|}{ 3- Heart rate } \\
\hline$-1^{\text {st }}$ week & $101.8+11.7$ & $90.4+11$ & 0.001 \\
\hline$-2^{\text {nd }}$ week & $99.6+7.6$ & $84+14.1$ & 0.001 \\
\hline P. value & 0.001 & 0.001 & \\
\hline
\end{tabular}


Figure (2): Patients distributionin relation tothe internal jugular venous access complications in the both groups through the two weeks.

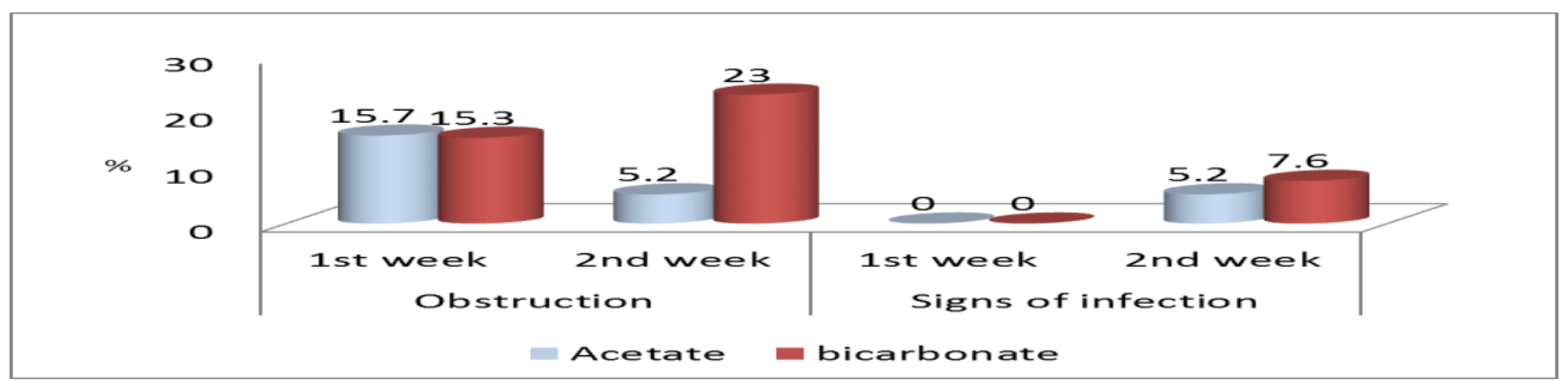

Figure (3): Percentages distributions of femoral venous access complications between the studied groups through two weeks.

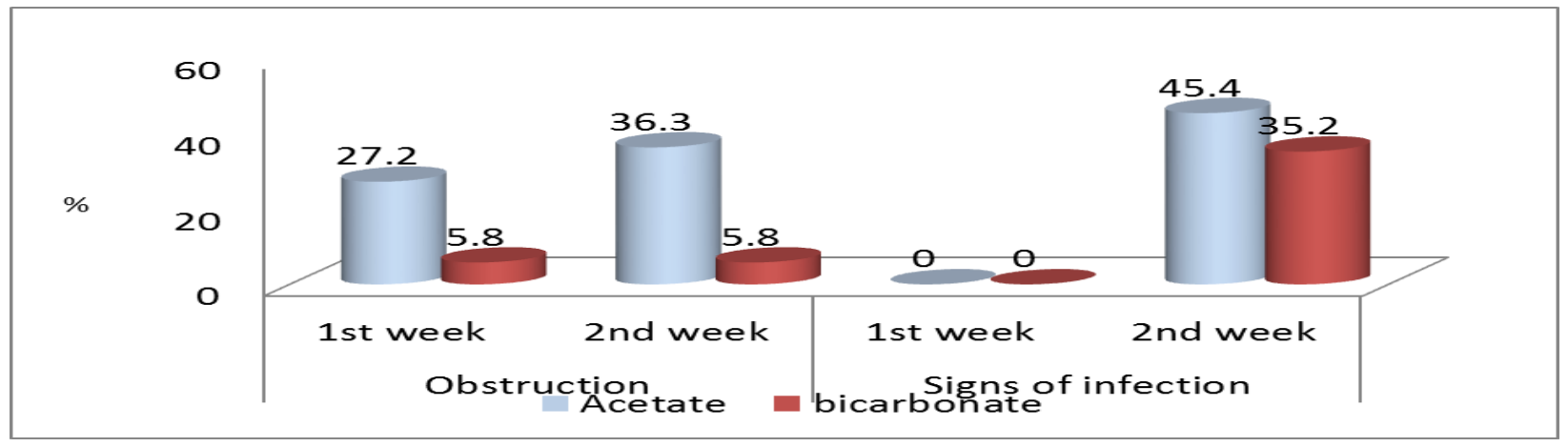

4: Comparison between the studied groups in relation to the mean and standard deviation of blood picture before and after dialysis session through the two weeks.

\begin{tabular}{|c|c|c|c|c|c|}
\hline \multirow{3}{*}{$\begin{array}{l}\text { Variables } \\
\text { 1-Hemoglobin value } \\
--^{\text {st }} \text { week } \\
-2^{\text {nd }} \text { week }\end{array}$} & \multicolumn{2}{|c|}{$\begin{array}{l}\text { Acetate group } \\
\text { Mean\& SD }\end{array}$} & \multicolumn{2}{|c|}{$\begin{array}{c}\text { Bicarbonate group } \\
\text { Mean\& SD }\end{array}$} & \multirow[t]{2}{*}{ T. test } \\
\hline & Before & After & Before & After & \\
\hline & $\begin{array}{l}10.55 \pm 1.55 \neq \\
9.82 \pm 0.8 \neq\end{array}$ & $\begin{array}{c}7.65 \pm 2.03 \neq \\
8.64 \pm 1.2 \neq \\
\end{array}$ & $\begin{array}{c}10.28 \pm 1.43 \neq \\
9.32 \pm 0.99 \neq \\
\end{array}$ & $\begin{array}{l}7.68 \pm 1.76 \neq \\
8.49 \pm 0.91 \neq\end{array}$ & \multirow[t]{2}{*}{$\begin{array}{l}0.951 \\
0.842\end{array}$} \\
\hline Pvalue & $0.025^{*}$ & $0.025^{*}$ & $\mathrm{0.003}^{*}$ & $0.029 *$ & \\
\hline $\begin{array}{l}\text { 2-Hematocrit } \\
-1^{\text {st }} \text { week } \\
-2^{\text {nd }} \text { week } \\
\end{array}$ & $\begin{array}{c}32.95 \pm 5.36 \\
30.64 \pm 3.9 \\
\end{array}$ & $\begin{array}{l}30.68 \pm 6.98 \\
29.45 \pm 6.15\end{array}$ & $\begin{array}{l}33.72 \pm 3.66 \\
30.77 \pm 3.55 \\
\end{array}$ & $\begin{array}{c}31.21 \pm 5.01 \neq \\
29.25 \pm 4.01\end{array}$ & \multirow{2}{*}{$\begin{array}{l}0.423 \\
0.123\end{array}$} \\
\hline P value & 0.061 & 0.471 & 0.002* & 0.099 & \\
\hline $\begin{array}{l}\text { 3-Red blood cells } \\
-1^{\text {st }} \text { week } \\
-2^{\text {nd }} \text { week }\end{array}$ & $\begin{array}{l}3.64 \pm 0.73 \\
3.36 \pm 0.56\end{array}$ & $\begin{array}{l}3.41 \pm 0.85 \\
3.27 \pm 0.67\end{array}$ & $\begin{array}{c}3.67 \pm 0.63 \\
3.1 \pm 0.52\end{array}$ & $\begin{array}{l}3.38 \pm 0.82 \\
3.25 \pm 0.72\end{array}$ & \multirow[t]{2}{*}{$\begin{array}{l}0.097 \\
0.246\end{array}$} \\
\hline P value & 0.101 & 0.481 & $0.001^{*}$ & 0.516 & \\
\hline $\begin{array}{l}\text { 4- White blood cells } \\
-1^{\text {st }} \text { week } \\
-2^{\text {nd }} \text { week }\end{array}$ & $\begin{array}{l}9.59 \pm 2.17 \\
8.82 \pm 2.13\end{array}$ & $\begin{array}{c}10.84 \pm 3.01 \neq \\
12.15 \pm 2.7 \neq\end{array}$ & $\begin{array}{c}9.87 \pm 2.4 \\
8.87 \pm 2.55\end{array}$ & $\begin{array}{c}12.3 \pm 3.5 \neq \\
10.89 \pm 1.9 \neq\end{array}$ & \multirow[t]{2}{*}{$\begin{array}{l}0.048 \\
0.032\end{array}$} \\
\hline P value & 0.081 & 0.171 & 0.057 & 0.123 & \\
\hline
\end{tabular}

Chi-square test - Independent samples T- test Statistical significant difference, $* *=(\mathrm{P}<0.005)$ paired T-test $(\neq)$ used to compare between before and after each group 
Table 5: Comparison between both groups in relation to the mean \& standard deviation of the coagulation profile before and after dialysis session through two weeks.

\begin{tabular}{|c|c|c|c|c|c|}
\hline \multirow[t]{2}{*}{ Coagulation tests } & \multicolumn{2}{|c|}{$\begin{array}{c}\text { Acetate group G1 } \\
\text { Mean\& } \& \text { SD }\end{array}$} & \multicolumn{2}{|c|}{$\begin{array}{c}\text { Bicarbonate group G2 } \\
\text { Mean\& } \pm \text { SD }\end{array}$} & \multirow[t]{2}{*}{ T. test } \\
\hline & Before & After & Before & After & \\
\hline $\begin{array}{l}\text { 1-Partial thromboplastin } \\
\text { time(PTT) } \\
-1^{\text {st }} \text { week } \\
-2^{\text {nd }} \text { week }\end{array}$ & $\begin{array}{c}37.6 \pm 8 \neq \\
40.3 \pm 9.9 \neq\end{array}$ & $\begin{array}{l}26.57 \pm 4.9 \neq \\
27.23 \pm 6.1 \neq\end{array}$ & $\begin{array}{c}35.6 \pm 6.9 \neq \\
40.2 \pm 10.4 \neq\end{array}$ & $\begin{array}{c}26.67 \pm 4.8 \\
\neq 27.98 \pm 6.05 \neq\end{array}$ & $\begin{array}{l}0.784 \\
0.842\end{array}$ \\
\hline $\mathrm{P}$ & 0.252 & 0.649 & 0.048 ** & 0.360 & \\
\hline $\begin{array}{l}\text { 2-Prothrombin Time(PT) } \\
-1^{\text {st }} \text { week } \\
-2^{\text {nd }} \text { week } \\
\end{array}$ & $\begin{array}{r}11.9 \pm 0.9 \neq \\
17.6 \pm 2.33 \neq\end{array}$ & $\begin{array}{c}12.4 \pm 1.19 \neq \\
14.77 \pm 1.85 \neq\end{array}$ & $\begin{array}{c}12.5 \pm 3.31 \\
14.7 \pm 1.4\end{array}$ & $\begin{array}{l}13.27 \pm 1.62 \\
15.07 \pm 0.79\end{array}$ & $\begin{array}{l}0.241 \\
0.342\end{array}$ \\
\hline$P$ & $0.001 * *$ & $0.001 * *$ & $0.001 * *$ & $0.001 * *$ & \\
\hline
\end{tabular}

Paired test $(\neq)$ had used between before and after each group.

Chi-square test - Independent samples T- test

Table 1: presentsthe characteristics of the studied patients in the acetate and bicarbonate groups.It can be seen that the mean age of the acetate group (G1) and bicarbonate group (G2) equal $41.9 \pm 10$ and $38.6 \pm$ 13.7 respectively. There was nostatistical difference between the both groups in relation to the age. Concerning the genderit was found that $36.7 \%$ of the studied patients in G1 were males, and it was $50 \%$ in $\mathrm{G} 2$, whileit was $63.4 \%$ and $50 \%$ respectivelyfemales in G1and G2, there was nostatistical difference between the both group.

Figure 1: Shows the percentage distribution of the studied patients in the both groups in relation to the predisposing factors of acute renal failure.It was foundthat $40 \%, 23 \%$, and $20 \%$ of the acetate group were experiencing renal stone \&pyelonephritis, lupus nephritis respectively. While, $36.6 \%, 20 \%, 10 \%$ and $8.8 \%$ respectively of the studied bicarbonate group were suffering of post partum hemorrhage, multiple trauma and renal stone \&pyelonephritis respectively. There was no statistical difference between the both groups.

Table 2: shows the vital signs values before and after dialysis session in the both groups. As for the values of thebody temperature therewas no statistical significant differencewas found between the both groups in the two weeks. While there was highly significant difference between the both groups in the respiratory rate, with $\mathrm{p}$ value $=0.007$ and 0.004 respectively in the two weeks.

Concerning the systolic and diastolic blood pressure, G1 had decrease in blood pressure after dialysis session with mean $92.3 \pm 21.2$ and $58.5 \pm 10.7$ respectively. While G2, had normal systolic and diastolic blood pressure after the dialysis in the $2^{\text {nd }}$ week with mean $105 \pm 28$ and $80.1 \pm 16.6$ respectively.
Statistical significant difference** $(\mathrm{P}<0.005)$

There was highly statistical significant difference between the both groups with $p=0.001$.

Table 3: shows the comparison between the both groups in relation to the vital signs values during the dialysis sessions. Regarding thebody temperature during hemodialysis, there was no statistical significant difference found between the both groups in the two weeks. While, there was highly statistical significant differences between the both groups in the respiratory rate with $\mathrm{p}=0.001$ and 0.046 respectively. Concerning the heart rate, there was an increase in the heart rate in G1 during the dialysis session, while G2 had normal heart rate. There was highly statistical significant difference between the both groups in the two weeks with ( $\mathrm{p}=0.001$ ).

Figure 2: presents the percentages distribution of the patients in relation to the internal jugular venous access complications for the both groups through the two weeks.It was found that $15.7 \%$ and $15.3 \%$ of the sample in the both groups were obstructed respectively in the first week, but it was $5 \%$ and $23 \%$ in second week. It was infected in 5.2\% and $7.6 \%$ of the sample in the both groups in second week respectively. There was no statistical difference between the studied groups in the two weeks.

Figure 3: indicates the percentages distributions of the femoral venous access complications in the studied groups through two weeks. It was found that the access was obstructed in $27 \%$ and $5.8 \%$ of the sample in the G1, and G2 respectively in the first week, and it was $36.3 \%$ and $5.8 \%$ in the both in $2^{\text {nd }}$ week. While it was infected in $45.4 \%$ and $35.2 \%$ in G1and G2 respectively in the $2^{\text {nd }}$ week. There was a statistical difference in the studied groups in the two weeks with $\mathrm{p}$ value $=0.001$.

Table 4: Indicates the comparison between the studied groups in relation to the mean and standard 
deviation of blood picture before and after dialysis sessions through the two weeks.Concerning hemoglobin value, it was decreased after dialysis session in the both groups with mean of $7.65 \pm 2.03$ and $7.68 \pm 1.76$ respectively in the both groups. There was a highly statistical significant difference before and after the sessionswith $\mathrm{p}=0.001$. Hematocrit was decreased after dialysis in both groups with mean of $30.68 \pm 6.98$ and $31.21 \pm 5.01$, with statistical significant difference in the two weeks, and with no statistical significant difference between the both groups.

There was no statistical significant difference between the both groupsin relation to red blood cells and platelets values. While, there was an increase in the number of the white blood cellsafter the dialysis sessions in the both groups, and there was a highly statistical significant difference in the studied groups in this respect with $\mathrm{p}=0.048$ and 0.032 .

Table 5: reveals comparison between the both groups in relation to the mean \& standard deviation of coagulation profile before and after dialysis sessions through the two weeks. It was found that thepartial thromboplastin time slightly decreased in the both groups through the two week, withno statistical significant difference between the both groups in the two weeks. However prothrombin time was increased above normal range in G2. There was a highly statistical significant difference between the both groups before and after the dialysis sessions $\mathrm{p}=0.071$ and 0.001 in G1. There was a highly statistical significant difference between the two groups in the two weeks with $\mathrm{p}=0.001$.

\section{Discussions:}

Critically ill patients with acute renal failure who are receiving dialysis therapy may suffer from many complications that can be decreased by using bicarbonate dialysate during dialysis sessions.It was documented that those patients may experience longer length of hospital stay, and the mortality rate may rise dramatically. (kellum, 2008)

Acute renal failure may lead to number of complications, including metabolic acidosis, high potassium and blood urea levels, changes in the body fluid balance, and other effects to the organ systems. Symptoms of acute kidney injury result from various disturbances of kidney function that are associated with the disease. Accumulation of urea and other nitrogen-containing substances in the blood stream lead to a number of symptoms, such as fatigue, loss of appetite, headache, nausea and vomiting, with marked increases in the potassium level that can lead to dysrhythmia (Wesberg, 2009).
The critical care nurse is in a good position to confront these complications by assessing and monitoring the patient's response to maintain hemodynamic stability during hemodialysis. The critical care nurse is providing daily care for the patients on hemodialysis focuses on the early detection and prevention of complications that may experienced by the patients during hemodialysis and providing proper nursing management (Gonce et al 2010)

Results of the current study presented that the majority of the both groups were in age groupof 40 to less than 60 years with mean of $41.9 \pm 10$ and $38.6 \pm 13$ respectively. This can be attributed to the higher exposure of younger male adult to trauma, systemic hypertension and renal stone related to some metabolic errors than female. While females may be more prone to exposure of post partum hemorrhage. This is disagreement with Jonathan et al 2010 who reported that, the age more than seventy years old. On other hand, Gold manet al 2012 who indicated that, the age more than fifty years old.

Regarding the predisposing factors for acute renal failure, the present study revealed that, more than thirty Percent of the sample in acetate group (G1) experienced acute nephritis\& chronic renal stone, septic shock, lupus nephritis \& hypertension, while in bicarbonate group $(\mathrm{G} 2)$ experienced multiple trauma, post partum hemorrhage and renal stone\& nephritis.This finding was in line with Malhis et al 2010 whom reported that, any ischemic or toxic causes at the site of the nephron places the patients at risk of ARF as hemorrhage and severe dehydration. Any obstruction in the flow of urine may lead to post renal as chronic renal and ureter stone causes ARF.

Regarding the vital signs in hemodialysis, the findings of current study revealed that the majority of the both groups had normal range of temperature before, during and after hemodialysis session. This finding may be attributed to that all patients had received antibiotics medications. There was no statistical significant difference between the both groups. This finding was in agreement with Gabutti et al 2009 who reported that the dialysate solutions had no any effect on the patients' temperature. On the opposite, Shoichiro et al 2011 reported that acetate hemodialysis may evoke increase in the temperature post dialysis session.

Concerning the respiration, the findings of present study indicated that the majority of the both groups had dyspnea and tachypnea in acetate group during and after dialysis session. This finding attributed to that the most of the patients had hypotension during dialysis session. Highly statistical significant differencewas found between both groups with $\mathrm{p}$ 0.007 and 0.004 . This finding was in line with 
Gabutti et al 2009 who proved that in acetate hemodialysis the patients may experience tachypnea and shortness in breathing due to hypotension during hemodialysis session.

As regard the heart rate, the majority of the studied patients in the current study presented normal heart rate before and after dialysis session in acetate group. While in bicarbonate group they experienced bradycardia after dialysis session.A statistical significant differencewas found between the both groups with $\mathrm{p} 0.001$ and 0.002 . This finding may be attributed to that most of the patients had hypotension during dialysis session. This finding was in agreement with Saitos et al 2009 who revealed that, tachycardia during and after dialysis session. Another point of view, Gabutti et al 2009 reported that, patients in acetate and bicarbonate groups experienced normal heart rate during dialysis session. In this respect Gonce et al 2010 recommended that the critical care nurses should do close observation to the patients during the hemodialysis session and perform frequent monitoring to the vital signs every half an hour.

Concerning the blood pressure, the findings of the current study reported that the majority of the patients in acetate group experienced hypotension during and after dialysis sessions. While in bicarbonate group patients had normal blood pressure during hemodialysis session. This may be attributed to the disease process and that the most of the patients in the acetate group had received intravenous saline and this may increase the sodium conductivity, and the acetate dialysate had vasodilator effect. Astatistical significant differencewas observed between the studied groups, and between before and after dialysis in the each group with $\mathrm{p} 0.001$. This finding wasin agreement with shoichiro et al 2011who reported that, the acetate dialysate cause hypotension during and post dialysis session.

Regarding femoral venous access complications, the current study revealed that, $36 \%$ and $45 \%$ of the patients in the both groups respectively show signs of infection in the $2^{\text {nd }}$ week. This may be attributed to the low applications of universal precautions in caring for femoral access. There was no statistical significant difference between the both groups. This finding was in agreement with Vanholder et al 2010 who reported thatthe femoral accesswas found to be ina higher risk of infection than the internal jugular access, and therefore it should be avoided to use as much as possible. In this respect, Jonathan et al 2010 reported that the critical care nurse should be caring in the management of the temporary vascular venous access daily under aseptic technique and should avoid use it for aspiration of the blood sample. As for the blood picture in the both studied groups, findings of current study revealed that the majority of the patients in both groups were experienced decrease hemoglobin, hematocrit, red blood cells and platelets after all hemodialysis sessions. This finding may be attributed to the disease processsuch as post partum hemorrhage and multiple trauma patients and frequent blood sample for renal function tests, arterial blood gases and electrolytes. So the critical care nurse should replace the blood loss to the patient as doctor order and iron and to correct the anemia.

Moreover, majority of the patients in the both groups experienced increase in the white blood cells. This may bedue to the increased rate of infection in the venous catheter and blood stream during hemodialysis sessions.A statistical significant difference was observedbetween the both groups with p 0.048 and 0.032 . Therefore, the critical care nurse should perform the hemodialysis procedure following the universal precautions for infection control. This finding was in agreement with Gonce et al 2009, and Basile et al 2011 who reported that the majority of the patients on hemodialysis were experienced anemia due to drop in the level of hemoglobin and hematocrit.

Concerning coagulation parameters, findings of present study revealed that the majority of the patients in acetate group experienced that the partial thromboplastin time and prothrombin time were slightly increased. A statistical significant difference wasfound in the two weeks, with $\mathrm{p}$ value 0.001 . This finding may be related to the patients in both groups were received primary dose of heparin. This finding was in agreement with results of John and Todd 2007. Another point of view presented by Vareesangthip et al 2011 who documented that Prolonged activated partial thromboplastin times (aPTT) at 30 minutes after hemodialysis were reported in the both groups. Contrary to that, Gabutti et al 2009 documented that coagulation parameter during hemodialysis was not influenced by the choice of dialysate fluids.

Conclusion and Recommendations:

Based on the findings of the present study, it can be concluded that studied patients in bicarbonate dialysate solution group experienced low complications as (hypotension, hypoxemia, metabolic acidosis, arrhythmias, nausea, vomiting and headache) rather than acetate dialysate solution group on hemodialysis with statistical significant differences between the both groups. Monitoring and proper management of the patients with acute renal failure is very important for reducing hemodialysis complications.

Based on the study findings, the following recommendations are suggested: 
1. Developing nursing strategies aiming at improving the quality of hemodialysis practices.

2. Bicarbonate dialysate solution should be used in hemodialysis to reduce the complications during dialysis.

3. Antihypertensive drugs should not be given before dialysis session to reduce hypotension episodes in acetate dialysis.

4. Replication of this research on a larger probability sample acquired from different geographical areas in Arab republic of Egypt for generalization.

\section{References:}

1- Abbotti K, Neff R\&Bohen E., (2007): Anticoagulation for atrial fibrillation in hemodialysis. American Journal Kidney Diseases; 50(3):1345-1348.

2- Agraharker M., (2009):Acute renal failure. Emergency medicine; 22(1): 345-352.

3- Basile C., Libutti P\&Luro L., (2011): Hemodynamic stability in standard bicarbonate hemodialysis, Nephrology Dialysis Transplantation; 26(2): 252-8.

4- Buemi M., Coppolino G, Bolingnano P., Slurial A, Campos, BuemiA\& Craci E. (2009): Arrhythmias and hemodialysis role of potassium and new diagnostic tool. Renal failure Journal; 31(1):75-80.

5- Gabutti L, Ferrari N., Giudici G., Mombelli C\&Marone C., (2009): Unexpected hemodynamic instability association with standard bicarbonate. Nephrology Dialysis Transplant; 24(3): 937-81.

6- Galbusera M., RemuzziG\&Boccardo P., (2009):Treatment of bleeding in dialysis patients. Seminar Dialysis; 22(1): 279-86.

7- Goldman, Fontaine D., Carolyn N., \& Barbara M., (2012):Critical Care Nursing A Holistic Approach $9^{\text {th }}$ ed. Philadelphia: Lippincott Williams\&Willkers: 758-760.

8- Gonce P., Fontaino D., Carolyn M\&Barabara M. (2010): Critical Care Nursing a Holistic Approach. 8ed by Lippincott Williams\&Willkers: 890-8.

9- Heitor F., Borges D., David S, Alberto A., \& Carlo M., (2009):Hypotension during Acetate \& Bicarbonate dialysis in patients with acute renal failure. American Journal of nephrology; 21(1): 7-12.

10- John T and Todd S., (2007): Hand book of Dialysis $2^{\text {nd }}$ ed. Boston, New York: Little brown and company: 210-8.

11- Jonathan H., Joseph W, Mohammed H\& Raja N., (2010):Kidney Diseases, Dialysis and
Transplantation $2^{\text {rd }}$ ed. Philadelphia: Saunders an imprint of Elsevier Inc: 945-77.

12- Kais H., Hichri N, Chakib M., Tagorti M\& Ahmed A., (2008): Variability of acid base status in Acetate free biofiltration $84 \%$ versus Bicarbonate dialysis, Seminar Dialysis; 26(2): 351-64.

13- Lameire N., (2010):The pathophysiology of acute renal failure. Critical Care Clinic; 21(2):197-210.

14- Levin N., Zhu F., \& Keen M., (2007):Interdialytic weight gain and dry weight. Blood purification; 19: 214-120.

15- Malhis M., Al-Bitar S, FarhoodS\&Zaiat K., (2010): Changes in QT intervalsin patients with acute renal disease before and after hemodialysis. Saudi Journal Kidney Dis Transplant; 21(1): 460-5.

16- Morath C., MiftariN\&Dikow R., (2009):Sodium citrate anticoagulant during sustained low efficiency dialysis in patients with acute renal failure. Nephrology Dialysis Transplant; 23(10): 421-2.

17- Saitos T, Saito O., Maeda T, Loto C., \& Ando Y., (2009):Metabolic and Hemodynamic advantages of an acetate free citrate dialysate. American Journal of Kidney Diseases; 54(4): 764-9.

18- Sastri S., and Sanak M., (2010): Cardiovascular disease and ARF: Core curriculum. American Journal Kidney; 56(2): 399- 414.

19- Shoichiro D., Ksuzush D., \& Mitsuhiro K., (2011):Comparison of acetate hemodialysis Bicarbonate hemodialysis regarding the effect of intra-dialysis hypotension, Therapeutic aphaeresis and Dialysis; 15(2): 460-465.

20- Vanholder R, Bernard C., Canaud A., Richard F., Michel J., \& Laura L., (2010):Diagnosis, prevention and treatment of hemodialysis catheter-related bloodstream infections: a position statement of European. Nephrology dialysis transplantation; 3(2): 23446

21- Vareesangthip K., Thitiarchakul S., Kanjanakul I, Sumethkul V, Krairittichai U., ChittinandanaA\&Bannachak D., (2011):Efficacy and safety of enoxaparin during hemodialysis.Journal Medicine Association Thailand; 94(1): 21-6. 